\title{
PERFORMANCE IN HOME SCHOOLING: AN ARGUMENT AGAINST COMPULSORY SCHOOLING IN THE NETHERLANDS
}

\author{
HENK BLOK
}

\begin{abstract}
Although home education is a growing phenomenon in many Western countries, it is almost non-existent in the Netherlands. Under Dutch educational law, children must be educated in the school system. Home schooling is thought to endanger children's development. This study examines - primarily American - analyses of performance in home schooling. Its leading question is: How do home-schooled children develop in comparison with school pupils? It concludes that home-schooled children perform better on average in the cognitive domain (language, mathematics, natural sciences, social studies), but differ little from their peers at school in terms of socio-emotional development. This positive finding may be attributed partly to socioeconomic factors. However, it is also suggested that the quality of the learning environment, including one-to-one tutoring, could also be a contributing factor.
\end{abstract}

Zusammenfassung - LEISTUNGEN IM HAUSUNTERRICHT: EIN ARGUMENT GEGEN DIE ÖFFENTLICHE SCHULPFLICHT IN DEN NIEDERLANDEN Obwohl sich der Hausunterricht zunehmend in vielen westlichen Ländern beobachten lässt, ist sie in den Niederlanden fast nicht vorhanden. Nach dem holländischen Erziehungsgesetz müssen die Kinder im öffentlichen Schulsystem ausgebildet werden. Man glaubt, dass der Hausunterricht die Entwicklung der Kinder gefährde. Die Studie untersucht - vor allem amerikanische - Übersichten über die Leistungen, die im Hausunterricht erbracht werden. Ihre leitende Frage ist: Wie entwickeln sich Kinder im Hausunterricht verglichen mit Schülern der öffentlichen Schule? Ihr Ergebnis ist, dass die Kinder im Hausunterricht durchschnittlich bessere Leistungen in den verschiedenen Wissensgebieten erbringen (Sprachen, Mathematik, Naturwissenschaften, Gemeinschaftskunde) und sich nur wenig von den Schülern der öffentlichen Anstalten unter dem Aspekt ihrer sozialen und emotionalen Entwicklung unterscheiden. Dieses positive Ergebnis mag sich teilweise auf soziale und ökonomische Faktoren zurückführen lassen. Es liegt jedoch auch nahe, dass die Qualität des Lernmilieus, wozu auch die Einzelbetreuung gehört, gleichfalls zu diesem Ergebnis beiträgt.

Résumé - RESULTATS DE L'ENSEIGNEMENT A DOMICILE : UN ARGUMENT CONTRE LA SCOLARITE OBLIGATOIRE AUX PAYS-BAS - Si l'enseignement à domicile est un phénomène croissant dans de nombreux pays occidentaux, il est presque inexistant aux Pays-Bas. Selon la loi néerlandaise en matière d'éducation, les enfants doivent être instruits au sein du système scolaire. L'instruction privée est considérée comme un danger pour le développement infantile. L'auteur de cette étude a analysé les résultats - essentiellement américains - de l'enseignement à domicile. Sa question majeure était la suivante: Comment les enfants instruits à domicile se développent, comparés aux écoliers traditionnels ? Il conclut que les premiers fournissent en moyenne de meilleurs résultats dans le domaine cognitif (langues, mathématiques, sciences naturelles, sciences sociales), et ne diffèrent que peu de leurs pairs inscrits dans le système scolaire quant à leur développement socioémotionnel. Ces résultats positifs peuvent être partiellement attribués aux facteurs socioéconomiques. Mais l'auteur suppose que la qualité de l'environnement éducatif,

International Review of Education - Internationale Zeitschrift für Erziehungswissenschaft - Revue Internationale de l'Education 50(1): 39-52, 2004.

(c) 2004 Kluwer Academic Publishers. Printed in the Netherlands. 
comprenant l'instruction sous forme de cours particulier, constitue également un élément stimulant.

Resumen - EL RENDIMIENTO EN LA ENSEÑANZA EN CASA: UN ARGUMENTO CONTRA LA ESCOLARIZACIÓN OBLIGATORIA EN LOS PAÍSES BAJOS - Pese a que la escuela en el hogar sea un fenómeno creciente en muchos países occidentales, en los Países Bajos sigue sin existir. Según las leyes nacionales holandesas, los niños deben ser educados en el sistema escolar. La escuela en la casa es considerada un riesgo para el desarrollo de los niños. El presente trabajo examina los informes, ante todo norteamericanos, realizados sobre el rendimiento en la educación a domicilio. Su principal interrogante es: ¿Cómo se desarrollan los niños bajo una enseñanza en casa en comparación con los alumnos escolarizados? El autor concluye que, en promedio, los niños de enseñanza a domicilio muestran mejores rendimientos en el área cognitiva (lenguas, matemáticas, ciencias naturales y sociales), a la vez que difieren poco de sus pares escolarizados en cuanto a su desarrollo socio-emocional. Este resultado positivo podría atribuirse, en parte, a factores socioeconómicos, pero también sugiere que la calidad del entorno de aprendizaje, incluyendo la enseñanza individual, pueden ser otros factores que contribuyen a estos resultados.

Резюме - ЭФФЕКТИВНОСТЬ ОБУЧЕНИЯ НА ДОМУ: АРГУМЕНТ
ПРОТИВ ОБЯЗАТЕЛЬНОГО ШКОЛЬНОГО ОБРАЗОВАНИЯ В НИДЕРЛАНДАХ - Несмотря на то, что домашнее обучение оказывается весьма быстро развивающимся явлением во многих западных странах, оно практически отсутствует в Нидерландах. Согласно голландскому закону об образовании, дети должны получать образование в рамках школьной системы. Считается, что домашнее обучение может представлять опасность для развития ребенка. В данном исследовании рассматриваются отчеты об эффективности домашнего обучения, составленные преимущественно в Америке. Основной вопрос состоит в том, насколько развитыми оказываются дети, обучающиеся на дому, по сравнению со школьниками. Обучающиеся на дому дети оказываются более развитыми в когнитивной сфере (языки, математика, естественные и общественные науки), хотя и несколько отличаются от своих посещающих школу сверстников с точки зрения социально-эмоциональной развитости. Эта положительная динамика может отчасти объясняться социально-экономическими факторами. В то же время следует отметить, что качество образовательного процесса, включая индивидуальные занятия, также может играть важную роль.

The term 'home schooling' is used with reference to parents who teach their children at home. Home schooling is often compared with school-based education, the institution of teaching children at school. Home schooling and school-based education can be seen as two extremes in a continuum. In an intermediate form, children would be taught in part by their parents, in part at school. Although such intermediate forms are theoretically feasible, they would signify little in practice. An example which does come to mind is the tutoring which parents, possibly working with remedial teachers, sometimes 
give children who might otherwise fall behind. The present study, however, will devote no further attention to intermediate forms of home schooling.

While it may appear to be a recent phenomenon, home-based education dates back farther than does education at school. Before schools ever existed, children were taught primarily at home. Even long after the evolution of school-based education was underway, home schooling remained a serious alternative. The Netherlands' first schools were established in the 8th or 9th century, monastic schools which taught pupils to read and write and prepared them for life in the clergy (Boekholt and De Booy 1987). Another thousand odd years passed before a secular government took on the task of establishing and managing a system of school-based education. During the 19th century, the Netherlands passed its first laws ever on schools and education. The year 1900 witnessed the introduction of the first Compulsory Education Act. This Act required parents to enroll children aged 7 to 13 in primary education. It did, however, allow parents the option of teaching their children at home. It was only when the revised Compulsory Education Act entered into effect in 1969 that parents were completely barred from teaching children at home. Afterward, home schooling no longer represented an alternative to education at school. The Dutch government, in defending its official position in the debate about the revised act, contended that home schooling conflicted with the interests of children.

Today, home schooling is practically non-existent in the Netherlands. The number of home-schooled children ('hs-children') is probably no more than a few hundred, accounting for less than $0.01 \%$ of the population of $4-$ to 18-year-old pupils. Their number is so insignificant that no effort has even been made to keep systematic records of them.

A century of compulsory education has established a tacit assumption that parents are incompetent to teach their own children. The accuracy of this view, however, is open to question. Many people who move abroad for temporary periods teach their children at home. Dutch parents can use the materials of an organization called the Wereldschool (World School), which compiles teaching packages with support from the government. The same organization also provides instructional advice on request. While this solution appears to be makeshift in a certain respect, it also shows that home schooling is a viable option.

Experiences in other countries appear to support this conclusion. In some European countries, whose legislation is less restrictive, children are increasingly being taught at home instead of attending school. These countries include Belgium, Denmark, France, England, Ireland, Italy, Norway and Portugal (Petrie 1995). In all probability, however, the number of home-schooled children in these countries still falls well under $1 \%$ of their school populations, although actual figures are unavailable.

Over the past decade, home schooling has gained considerable ground in the United States. In 1980, it was prohibited in 30 states. By 1993, however, it had been legalized in all 50 states under pressure from home-schooling 
organizations. The number of home-schooled children (aged 5 to 18) swelled from a few tens of thousands in the 1980 s to some 850,000 by 1999 . In terms of percentages, the latter figure represents $1.7 \%$ of all children in that age group. This estimate is based on official figures from the US Department of Education (Basham 2001). Organizations such as the National Home Education Research Institute place the estimate for the same year significantly higher, at 1.5 million children, or 3\% (Ray 1999). Whatever the case, home schooling has grown by leaps and bounds in the United States and is still on the rise.

Given these facts, the question of the effectiveness of home schooling is important. This study attempts to answer this question, formulated more specifically as follows: How do home-schooled children develop as compared with children in school-based education? In examining this comparative question, the focus will lie on the cognitive and socio-emotional development of children.

This study was designed as a literature review - the only option, inasmuch as home schooling is virtually non-existent in the Netherlands. The literature used here builds on experiences in other countries, primarily the United States. The concluding section considers whether experiences abroad are applicable in the educational context of the Netherlands.

\section{Method}

The literature for this study was selected from relevant bibliographical databases in social-science research. The most important of these were ERIC, PsycINFO and Dissertation Abstracts. Key words such as 'home school', 'home schooling', 'home education' and 'academic achievement' were employed in searching these databases electronically, along with the internet, especially the websites of home-schooling organizations (Education Otherwise in England as well as the Home School Legal Defense Association and the above-mentioned National Home Education Research Institute in the United States). For reasons of availability, the search was limited to literature published after 1985. In the end, eight studies relating to the development of home-schooled children were reviewed.

Percentiles were used to analyze the research findings and make them suitable for comparison. Ranging from 1 through 100, percentiles each represent exactly $1 \%$ of the scores. A percentile score of 1 , for example, would be assigned to those in the lowest $1 \%$ of the scores. Conversely, a percentile score of 100 would be assigned to those in the highest $1 \%$ of the scores. By definition, a percentile score of 50 would represent the average percentile score. 


\section{Results}

\section{Cognitive development}

Table 1 presents an overview of the source studies. Of the eight studies reviewed, seven were conducted in the United States and one in Canada. In total, 46,609 home-schooled children aged 6 to 19 participated in these studies. In examining the combined samples of the studies, there were at least 1,000 home-schooled children in each yearly age cohort from 6 to 19. A study by the ACTP and a second by Rudner (1999) account for a large segment of the combined subject population, with 17,000 and 20,000 home-schooled children, respectively. The children in both of these studies were recruited nationwide.

The studies were similar in their research structure. All of them included a fairly comparable group of children who had never been home-schooled. Social scientists refer to this as "static group design" (Campbell and Stanley 1963). Generally speaking, this design is considered weak, as it does little to exclude invalidating factors. One of the risks it entails is selection, a factor that would preclude any comparisons at all between the two groups of children. Indeed, the next section will reveal that selection mechanisms do come into play.

The tests administered measured scholastic achievement only, not intelligence. Barring the test used by Sutton and Oliveira (1995), these tests are reputable, high-quality instruments. They cover all basic subjects in regular school curricula: language (reading and writing), mathematics, social studies and science. American universities use the American College Test for student selection purposes. The other tests are large-scale instruments used to determine whether scholastic achievement in pupils and the quality of school curricula are up to standard.

Focusing on the results of most of these studies, the reader finds that homeschooled children achieve higher scores on average than do their peers in school. Tipton's study (1990) is the only one that did not find home-schooled children to have an advantage.

Cohen (1988) established general guidelines for interpreting the significance of differences. Expressed in percentile scores, they are:

$\begin{array}{ll}\text { small difference } & \text { a difference of roughly } 8 \text { percentile points } \\ \text { medium difference } & \text { a difference of roughly } 20 \text { percentile points } \\ \text { large difference } & \text { a difference of roughly } 30 \text { percentile points }\end{array}$

Applying these guidelines to the assessment of the differences found, the following configuration emerges. One study concludes that home-schooled children have neither an advantage nor a disadvantage (Tipton 1990). Three studies show home-schooled children to be at a small-to-medium advantage (ACT; Calvery et al. 1992; Sutton and Oliveira 1995). One study points to a medium advantage (Galloway 1995). Of the remaining three studies, one 


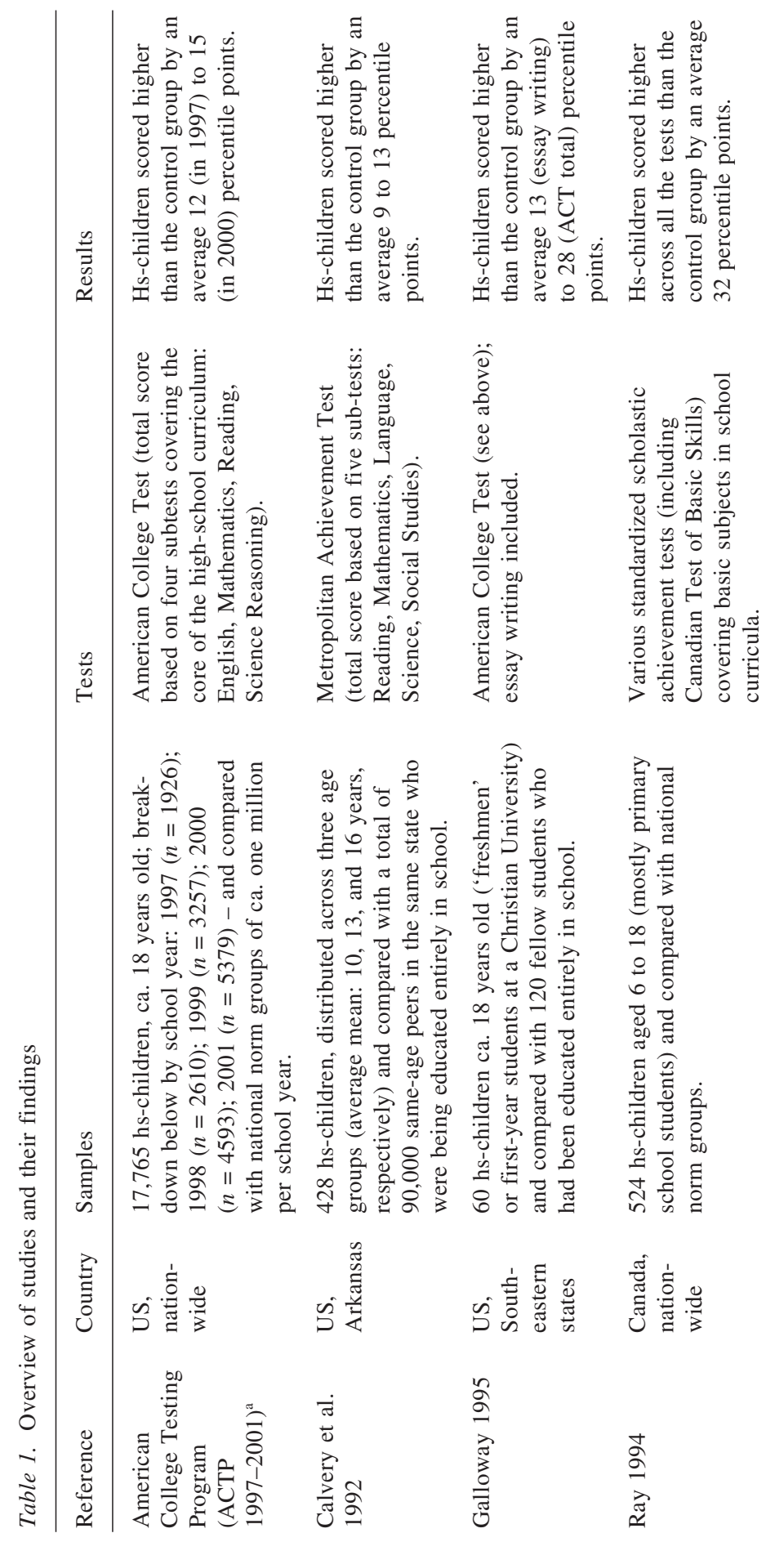


Performance in Home Schooling
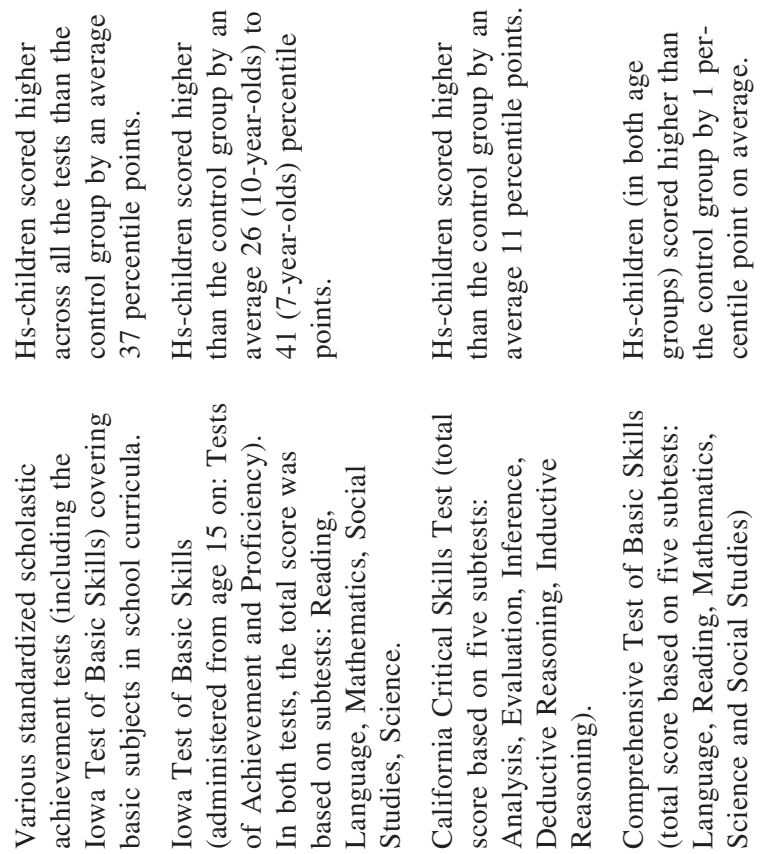

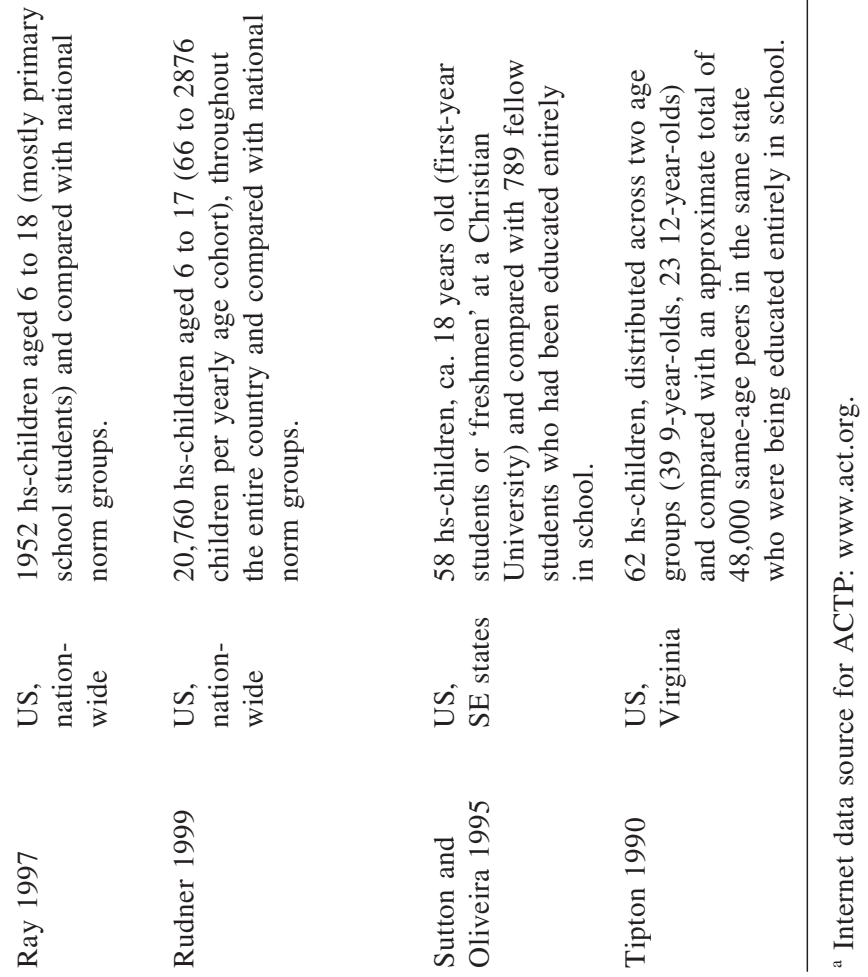


indicates a medium-to-large advantage (Rudner 1999), the other two a large advantage (Ray 1994, 1997).

A case study: Rudner (1999)

Rudner's study (1999) merits extra attention for a number of reasons. For one thing, it was the study with the largest sample of home-schooled children. It also illustrates the limitations encountered in the other studies discussed here. Finally, it points towards some interesting ancillary findings.

Rudner's data source was the Testing and Evaluation Service of the Bob Jones University Press. This is one of four major institutions in the United States offering home-schooling parents a testing service for a fee. Some parents use the service primarily for their own purposes, including the independent assessment of their children's academic progress. Others use the scores to satisfy testing requirements in their states. Various states in the United States require home-schooling parents to report their children's progress on an annual or biennial basis.

The procedure is as follows. Parents register their children, specifying their grade in school. The Bob Jones University Press then sends them the testing materials. Following detailed instructions, the parents administer the tests themselves. Scoring and analysis takes place centrally, after which the results are reported to the parents. Admittedly, this procedure is not completely fraud-proof. Nonetheless, an analysis of the data obtained - which were compiled in the spring of 1998 - would have exposed any significant cheating which might have taken place.

Findings from the accompanying survey revealed that these parents belong to a select group. They are better educated than average Americans and have higher incomes (even though most of the mothers do not hold paying jobs). Divorce is less common among them. More often than not, they are Caucasian and members of Christian churches. These factors are known to be positively associated with scholastic achievement in children. In addition, the distinctive status of Bob Jones University, depicted by Welner and Welner (1999) in terms of "racial intolerance" and "religious orthodoxy", could well add to the selective character of Rudner's sample.

As explained above, Rudner's study found the average home-schooled child to have gained a considerable edge. A number of observations are called for here. It is noteworthy that these children were found to be advanced in all of the different subject areas (language, reading, mathematics, social studies and science). In this light, their progress can be described as being greatly advanced. Significantly, one would find the same scholastic advancement in making an exclusive comparison with private-school pupils, who are known to score higher than their peers in state-run schools, or 'public schools' as they are called in the United States. One can also express this scholastic advancement in terms of school years. In that case, the average 6-year-old is approximately one school year ahead, a lead that gradually increases to 
roughly four school years among 14-year-olds. In other words, the average home-schooled 14-year-old has made as much academic progress as the average 18-year-old high-school graduate. These figures correspond almost entirely to those which Ray reports based on an independent sample (1997).

Additional analyses have revealed that children who were taught at home throughout all of their school years achieved higher scores than those homeschooled for only some of those years. Ray (1997) also arrived at this finding. Children with more educated parents or those in higher income categories also achieve higher scores. These findings should come as no surprise, given that social background is known to be a factor positively influencing scholastic achievement. What is surprising, however, is that this relationship is much less pronounced among home-schooled children than it is among those attending school (Ray 1997). It would appear that schools offer working-class children far less in terms of compensation than do home-schooling parents. In other words, working-class children appear relatively better off in homebased education than they are in the school system.

A number of other factors which might have been expected to show a positive effect also appeared to lack any positive association. Formal teaching qualifications proved, for example, to make no difference. Similarly, no difference was found between children taught with full service curricula and those whose parents used their own curricula.

Rudner cautions his readers - and rightly so - against drawing the simple conclusion that home schooling is better or more effective than school-based education. A conclusion of that nature would be plainly invalid, given that home-schooled children form a selective, privileged group. One would, however, be justified in concluding that parents who opt to teach their children at home, rather than enroll them in school, are able to provide a very successful academic environment.

\section{Socio-emotional development}

How do home-schooled children fare in terms of socio-emotional development? Do they learn to interact with others, children as well as adults? Do they develop such character traits as perseverance and self-confidence? The studies which have explored questions such as these are considerably fewer in number than those on scholastic achievement. Moreover, they have generally tended to be on a much smaller scale. The samples of home-schooled children in these studies range from no more than a few dozen to 224 (Taylor 1986).

Lee (1995) and Smedley (1992) compared the social skills of homeschooled children to those of school pupils. Lee found no differences between the two groups. Smedley, however, concluded that home-schooled children had better developed social skills and were more mature. Taylor (1986) focused on children's self-concepts, or self-images, a major part of which consists in their self-confidence. He found home-schooled children to have a 
significantly more positive self-concept than school pupils. Shyers (1992) also assessed the self-concepts of home-schooled children as well as their ability to stand up for themselves and to control problem behavior (such as fear and aggression). While Shyers found fewer behavioral problems in home-schooled children, he found no differences in terms of their self-concepts or assertiveness. Lattibeaudiere (2000) describes a study exploring how successfully former home-schooled children adapt when they enter higher education. It found that they adapted better socially and emotionally than did students who had gone through the established school system. Apostoleris (2000) focused on motivation for learning. While motivation declined with age in the average school pupil, it remained consistent, or even increased, in home-schooled children.

In reviewing these results, one would conclude that home-schooled children are as socially well adjusted as school pupils, if not more so. Incidentally, the assumption that home-schooled children would grow up isolated from other children is probably incorrect. Ray (1999) observes that many homeschooled children have siblings and participate in a variety of social activities, including sports and cultural pursuits (e.g., music, ballet, church). Bashem (2001: 13) also notes that home-schooled children take part regularly in numerous activities outside the home (on average some five regular or frequent activities per child). Almost every individual home-schooled child participates in at least two such activities per week. Networks of home-schooling parents probably also play a role. Virtually every American state has an organization for home schoolers. These organizations offer parents and children the opportunity to meet or go on excursions together.

\section{Conclusions}

Almost all of the studies discussed here point in the same direction. Homeschooled children stand out from their peers in schools in terms of scholastic achievement and - although less decisively - socio-emotional development. According to some studies, the average home-schooled child is ahead by a number of school years, which constitutes an undeniably strong lead. There is no evidence whatsoever to suggest that home-schooled children lag behind.

Again, one cannot conclude from the studies discussed here that home schooling is better for children than school-based education. In all probability, home-schooled children are a privileged group. Their parents are better educated, have higher incomes and undoubtedly feel a strong sense of commitment to their children's development. Consequently, it is unclear whether these children's advanced performance is attributable to a better head start, to the home-schooling itself or to a combination of these two factors.

The quality of the studies reviewed here leaves much to be desired. For one thing, the body of research is small. Also, the quality of the research is below par. Most of the studies work with small samples and lack a broad 
international base. Moreover, the (static-group) research design is weak. It will take more research - and better research methods - to gain a deeper understanding of the advantages and limitations of home schooling. Researchers should invest greater effort in using more sophisticated research methods, such as matching. They should also explore in more depth the practice of home schooling and its influence on the effectiveness of instruction. Does it make any difference, for example, whether parents use their own regular curriculum the way schools do, or whether they opt for more informal methods of learning, as described by Thomas (2002)?

How is it that home-schooled children can thrive academically? Many answers to this question would demonstrate that these children's good academic performance is not, in fact, surprising. Various educators have established that one-to-one tutoring, that is, a ratio of one teacher per student, is the most effective method of teaching (Bloom 1984; Cohen, Kulik and Kulik 1982; Glass, Cahen, Smith and Filby 1982). The renowned Benjamin Bloom even regards the science of teaching as a quest for methods of group instruction which are as effective as one-to-one tutoring. One-to-one tutoring is, in fact, gaining more and more ground in education despite the costs involved. It is being applied for such purposes as preventing and tackling reading disorders (Pinnell, Lyons, DeFord, Bryk and Seltzer 1994; Wasik and Slavin 1993).

Meighan (1995) mentions additional causes. He points out that almost all parents are, by nature, outstanding at coaching their children, including helping them learn to walk, toilet training them and stimulating their early linguistic development. Many of the skills children learn from their parents are as culturally tinged as the skills taught in schools. It is also important that parents be able to respond flexibly to the needs and desires that children express, for instance, about their favorite activities and the subjects which interest them. At home, children can ask questions almost endlessly, whereas school pupils are hampered by practical limitations. Use of instruction time is considerably more efficient at home than it is in schools, where children spend much of their time on exercises which they no longer need, or, conversely, which are too difficult for them.

The specific question arising from the present discussion is: Are the findings of these American studies applicable in the context of education in the Netherlands. Do (the few) home-schooling Dutch parents perform as well as their American counterparts? Needless to say, any conclusive answer would be impossible without researching the subject. However, the differences between educational environments in the United States and the Netherlands are fairly small. Both are very technologically advanced Western countries with a wide range of freely available information from sources such as television, newspapers, books and textbooks, libraries and the internet. Dutch parents opting to home-school their children could access and obtain the knowledge they need through countless channels. Those who wanted to could even work with the same textbooks used to teach children at school. Thus, 
there is little question that Dutch parents who would prefer home-based to school-based education could perform much on a par with home-schooling parents in the United States.

This last remark brings us finally to the Netherlands' policy of compulsory schooling. Scientifically speaking, there is nothing to support the view that home schooling is an academically inferior educational option. Nor does it appear to pose a threat to the interests of children, as contended in the debate concerning the Compulsory Education Act of 1969. To the contrary, there is solid evidence indicating that home schooling is not, by definition, detrimental to the interests of children. The time has come, therefore, to review this policy of compulsory schooling. There appears to be no scientific basis for equating compulsory education with compulsory schooling. In other words, learning is possible - if not more effective - at home.

\section{References}

American College Testing Program. http://www.act.org, accessed 26 August 2003.

Apostoleris, Nicholas H. 2000. Children's Love of Learning: Home Schooling and Intrinsic Motivation for Learning. Ph.D. dissertation, Clark University. Ann Arbor: UMI.

Basham, Patrick. 2001. Home Schooling: From the Extreme to the Mainstream. Vancouver: The Fraser Institute [http://www.fraserinstitute.ca/admin/books/files/ homeschool.pdf, accessed 26 August 2003].

Bloom, Benjamin. 1984. The 2 Sigma Problem: The Search for Methods of Group Instruction as Effective as One-to-one Tutoring. Educational Researcher 13(June/July): 4-16.

Boekholt, Petrus Th. F. M., and Engelina P. de Booy. 1987. Geschiedenis van de School in Nederland vanaf de Middeleeuwen tot aan de huidige Tijd [History of Schooling in the Netherlands from the Middle Ages until the Present]. Assen/Maastricht: Van Gorcum.

Calvery, Robert, et al. 1992. The Difference in Achievement between Home-schooled and Public-schooled Students for Grades Four, Seven and Ten in Arkansas. Paper Presented at the Annual Meeting of the Mid-South Educational Research Association, Knoxville, TN, 11-13 November 1992 [ED354248].

Campbell, Donald T., and Julian C. Stanley. 1963. Experimental and Quasi-experimental Designs for Research. Chicago, IL: Rand McNally.

Cohen, Jacob. 1988. Statistical Power Analysis for the Behavioral Sciences. 2nd ed. Hillsdale, NJ: Lawrence Erlbaum.

Cohen, Peter A., James A. Kulik, and Chen-Lin C. Kulik. 1982. Educational Outcomes of Tutoring: A Meta-analysis of Findings. American Educational Research Journal 19: $237-248$.

Galloway, Rhonda A. 1995. Home-schooled Adults: Are They Ready for College? Paper Presented at the Annual Meeting of the Educational Research Association, San Francisco, CA, 18-22 April 1995 [ED384297]. 
Glass, Gene V., Leonhard Cahen, Mary Lee Smith, and Nikola Filby. 1982. School Class Size. Beverly Hills, CA: Sage.

Lattibeaudiere, Vivien H. 2000. An Exploratory Study of the Transition and Adjustment of Former Home-schooled Students to College Life. Ph.D. dissertation, University of Tennessee. Ann Arbor: UMI.

Lee, Walter J. 1995. The Socialization of Home-schooled and Public-schooled Children. Ph.D. dissertation, University of La Verne. Ann Arbor: UMI.

Meighan, Roland. 1995. Home-based Education Effectiveness Research and Some of its Implications. Educational Review 47: 275-287.

Petrie, Amanda J. 1995. Home Educators and the Law within Europe. International Review of Education 41: 285-296.

Pinnell, Gay S., Carol A. Lyons, Diane E. Deford, Anthony S. Bryk, and Michael H. Seltzer. 1994. Comparing Instructional Models for the Literacy Education of Highrisk First Graders. Reading Research Quarterly 29: 9-39.

Ray, Brian D. 1994. A Nationwide Study of Home Education in Canada: Family Characteristics, Student Achievement, and Other Topics. Salem, OR: National Home Education Research Institute.

1997. Strengths of their Own - Home Schoolers across America: Academic Achievement, Family Characteristics, and Longitudinal Traits. Salem, OR: National Home Education Research Institute.

1999. Home Schooling on the Threshold. Salem, OR: National Home Education Research Institute.

Rudner, Lawrence M. 1999. Scholastic Achievement and Demographic Characteristics of Home School Students in 1998. Education Policy Analysis Archives 7(8), http://epaa.asu.edu/epaa/v7n8, accessed 26 August 2003.

Shyers, Larry. 1992. Comparison of Social Adjustment between Home and Traditionally Schooled Students. Ph.D. dissertation, University of Florida. Ann Arbor: UMI.

Smedley, Thomas C. 1992. Socialization of Home Schooled Children: A Communication Approach. Master's thesis, Radford University.

Sutton, Joe P., and Paulo C. M. Oliveira, 1995. Differences in Critical Thinking Skills among Students Educated in Public Schools, Christian Schools, and Home Schools. Paper Presented at the Annual Meeting of the Educational Research Association, San Francisco, CA, 18-22 April 1995 [ED390147].

Taylor, John W. V. 1986. Self-concept in Home Schooling Children. Ann Arbor: UMI.

Thomas, Alan. 2002. Informal Learning, Home Education and Homeschooling. In: The Encyclopaedia of Informal Education, ed. by Mark K. Smith, http:// www.infed.org/biblio/home-education.htm, last updated: 15 April 2002.

Tipton, Mark. 1990. An Analysis of Home-schooled Children's Comprehensive Test of Basic Skills Results and Demographic Characteristics of their Families. Master's thesis, Antioch University [ED336208].

Wasik, Barbara A., and Robert E. Slavin. 1993. Preventing Early Reading Failure with One-to-one Tutoring: A Review of Five Programs. Reading Research Quarterly 28: 179-200.

Welner, Kariane M., and Kevin G. Welner. 1999. Contextualizing Homeschooling 
Data: A Response to Rudner. Educational Policy Analysis Archives 7(13), http://epaa.asu.edu/epaa/v7n13.html, accessed 26 August 2003.

\section{The author}

Henk Blok is Senior Researcher in the SCO-Kohnstamm Institute for Educational Research at the University of Amsterdam. His doctoral dissertation, submitted there in 1987, focused on instructional objectives for a mother-tongue curriculum. His current research interests include literacy instruction, instructional objectives, home education, measurement and evaluation, and research syntheses.

Contact address: SCO-Kohnstamm Instituut, Department of Education, University of Amsterdam, Wibautstraat 4, 1091 GM Amsterdam, The Netherlands. E-mail: H.Blok@uva.nl. 